ISSN = 1980-993X-doi:10.4136/1980-993X
www.agro.unitau.br/ambi-agua
E-mail: ambi-agua@agro.unitau.br
Tel.: (12) 3625-4116

\title{
Studies on contaminant transport at an industrial waste dumpsite of Bangalore, India (doi:10.4136/ambi-agua.61)
}

\author{
Syed Abu Sayeed Mohammed ${ }^{1}$; Maya Naik² ${ }^{2}$ Sanaulla Pathapalya Fakruddin³; \\ Zulfiqar Ahmed Mohammed Nazeer ${ }^{3}$ \\ ${ }^{1}$ Faculty of Civil Engineering, HKBK College of Engineering, \\ \#22/1, Nagawara, Bangalore 560045, India \\ Email: abubms@rediffmail.com \\ ${ }^{2}$ Faculty of Civil Engineering, BMS College of Engineering, \\ Bull Temple Road, Bangalore 560019, India \\ Email: snmcvbms@gmail.com \\ ${ }^{3}$ Faculty of Engineering Chemistry, HKBK College of Engineering, \\ \#22/1, Nagawara, Bangalore 560045, India \\ Email: sanahkbk@rediffmail.com,zulfi_chem@yahoo.com
}

\begin{abstract}
Industrialization and urbanization has produced various types of wastes that sometimes are dumped in low-lying areas without proper treatment and engineering controls. Bangalore district has more than 60 illegal dumpsites consisting of either municipal or industrial waste. Government records indicate that more than 1,500 industries are working at various industrial areas and other locations around the city. In the present study an attempt has been made to characterize the Bommasandra industrial area dump site located at the south of Bangalore. This dump site is 15 to 20 years old and spreads on an area of 12.7 acres. Around 60 to 70 industries of all nature are located around this dump site. A large number of soil samples were collected and after site characterization of soil properties, an attempt has been made to predict the transport behavior of selected chemical species using available mathematical models and a program based on MATLAB- 7 to study the migration properties of these selected chemical species as a function of time. Also a model provided by USEPA DRASTIC has been used. The DRASTIC Index found for this dumpsite was 146; therefore, one can conclude that the studied dumpsite is moderately vulnerable to pollutants. The migrating behavior of cations such as sodium, calcium and anions such as sulphate, chloride were considered. It was observed that cations are better retarded in comparison to anions. This was attributed to exchangeable chemical reactions.
\end{abstract}

Keywords: Dump site; industrial waste; municipal waste; diffusion; advection; retardation; modeling; MATLAB.

\section{Estudos de transporte de contaminantes em um depósito de lixo industrial em Bangalore, Índia}

\section{RESUMO}

A industrialização e urbanização têm produzido vários rejeitos que muitas vezes são despejados em áreas baixas sem tratamento adequado e sem engenharia de controle. $\mathrm{O}$ distrito de Bangalore tem mais de 60 lixões ilegais resultantes de rejeitos industriais ou municipais. Registros do governo apontam mais de 1.500 indústrias instaladas em diversos setores 
industriais e outros locais em torno da cidade. No presente estudo foi feita uma tentativa de caracterização do lixão da área industrial de Bommasandra, localizada no sul de Bangalore. Esse local de entulho tem de 15 a 20 anos e ocupa uma área de 12,7 acres. Cerca de 60 a 70 indústrias de diversas naturezas se localizam ao redor desse local de entulho. Um grande número de amostras de solo foi coletado para a caracterização do local e, após o conhecimento das propriedades do solo, foi feita uma tentativa de previsão do comportamento do transporte das espécies químicas selecionadas com base em modelos matemáticos disponíveis e em um aplicativo com base no MATLAB - 7 para modelar o processo de migração dessas espécies em função do tempo. Também um modelo disponibilizado pela USEPA DRASTIC foi usado. O Índice DRASTIC calculado para esse lixão foi 146; portanto, pode-se concluir que esse local de entulho é moderadamente vulnerável a poluentes. $\mathrm{O}$ comportamento de migração de cátions como sódio, cálcio e anions como sulfato, cloreto foi analisado. Foi observado que os cátions são mais retardados quando comparados aos anions. Isto foi atribuído às reações químicas desses elementos.

Palavras-chave: Lixão; rejeito industrial; lixo municipal; difusão; advecção; retardamento; modelagem; MATLAB.

\section{INTRODUCTION}

Nowadays, human kind's increasing mastery of natural law has at no doubt brought an increased life expectancy and a higher quality of life for more people than ever before. It has also brought the risk of global calamity and impairment of human health. Many of the environmental problems we are dealing with today are an accumulation of more than 200 years of managing residuals of our domestic and industrial output in ways we now know to be inappropriate. Past practices have resulted in a number of contaminated sites in proportion to the industrial output. We are now facing the cost of dealing with current and future production and use of products in such a way that they do not impair the environment or human health now or in the future (Wentz, 1995).

\subsection{Sources of ground water contamination}

The sources of ground water contamination can be from diffuse sources like deep percolation from intensively farmed fields or from point sources like septic tanks, garbage disposal sites, cemeteries, mine spoils and oil spills or other accidental entry of pollutants into the underground environment and also from line sources of poor quality water, like seepage from polluted streams or intrusion of salt water from oceans. Contaminant transport through compacted soil media is controlled by a variety of physical, chemical and biological processes. The physical processes include diffusion, advection and dispersion. The chemical process usually includes sorption, dissolution/precipitation, complexation, hydrolysis/substitution and oxidation. The biological process includes decay, etc.. Even with the implementation of waste reduction, recycling and transformation technologies, disposal of solid waste in landfills remains an important component of solid waste management strategy.

\subsection{Pollution vulnerability assessment using DRASTIC model}

Groundwater is one of the most valuable natural resources. During the last two decades groundwater quality has emerged as one of the most important environmental issues confronting much of the world's populace. Increasing evidence of groundwater contamination in recent years, coupled with uncertainties regarding long-term human health effects, has heightened pressure on public agencies to better manage groundwater resources. There is an 
urgent need for rapid surveys of groundwater utilization, aquifer pollution vulnerability and subsurface contaminant load.

\subsection{DRASTIC model parameters}

DRASTIC model is a groundwater pollution vulnerability assessment spatial deterministic model. This model consists of seven hydro geologic key parameters to classify vulnerability or pollution potential of an aquifer. The parameters are weighted with respect to their relative importance to the pollution potential of the aquifer.

The DRASTIC model acronym is taken from the parameters:
D Depth to water table
R Recharge
A Aquifer media
S Soil media
$\mathrm{T}$ Topography (slope)
I Impact of vadose zone
C Hydraulic conductivity of the aquifer material

This work envisages the use of hydrogeologic parameters, with proper ranking and weightage to yield suitable indices known as DRASTIC indices, a concept developed by USEPA (Gajendragad et al., 1990). DRASTIC is a numerical ranking system to assess groundwater pollution potential in any hydro geologic setting, which has been derived using DRASTIC factors. Each factor has been evaluated with respect to the other to determine the relative importance of each factor. The system consists of three significant parts namely weight, ranges and ratings.

\subsection{DRASTIC Index}

The DRASTIC Index is given by:

$$
\mathrm{DI}=\mathrm{D}_{\mathrm{r}} \mathrm{D}_{\mathrm{w}}+\mathrm{R}_{\mathrm{r}} \mathrm{R}_{\mathrm{w}}+\mathrm{A}_{\mathrm{r}} \mathrm{A}_{\mathrm{w}}+\mathrm{S}_{\mathrm{r}} \mathrm{S}_{\mathrm{w}}+\mathrm{T}_{\mathrm{r}} \mathrm{T}_{\mathrm{w}}+\mathrm{I}_{\mathrm{r}} \mathrm{I}_{\mathrm{w}}+\mathrm{C}_{\mathrm{r}} \mathrm{C}_{\mathrm{w}}
$$

where, $\mathrm{r}$ - rating and $\mathrm{w}$ - weight assigned. Once DRASTIC index is computed, it is possible to identify areas, which are more likely to be susceptible to ground water contamination relative to others.

Table 1. DRASTIC Index Number.

\begin{tabular}{ccccc}
\hline Drastic Index & Low & Moderate & High & Very High \\
\hline Values & $1-140$ & $141-180$ & $181-230$ & $>230$ \\
\hline
\end{tabular}

The higher the DRASTIC index, the greater the relative pollution potential. The DRASTIC index can be further divided into four categories: low, moderate, high, and very high. The sites with high and very high categories are more vulnerable to contamination and consequently need to be managed more closely. The weights assigned are relative, therefore a site with a low pollution potential may still be susceptible to groundwater contamination (Gajendragad et al. 1990). 


\subsection{Modeling}

Predicting the movement of fluids and contaminants in geologic systems is often carried out using theoretical models. In this approach, the processes under examination are simulated by a set of governing equations that are solved by analytical or numerical methods. At present, it is exceedingly difficult to obtain accurate field data that quantitatively describe contaminant transport and fate variables. Under these circumstances, model validation, a necessary precursor to routine model use, is problematic. For this reason, experimental data obtained under well defined conditions are fundamental for (i) assessing the predictive capabilities of existing theoretical models; and (ii) guiding the formulation, and parameterization, of improved predictive models. Ground water models are used to predict the migration pathway and concentrations of contaminants in groundwater (Shakelford and Daniel, 1991).

\subsection{Breakthrough curves}

Break through curves represent temporal variation in the concentration of a solute at the effluent end of a column of porous material. Using the experimental data breakthrough curves (i.e., a plot of the effluent liquid concentration $\mathrm{C}$ divided by the influent concentration $\mathrm{C}_{\mathrm{O}}$ as a function of pore volumes of flow or time) can be plotted. One pore volume of flow is equal to the volume of the void space in the soil. By measuring a breakthrough curve, the effective porosity of the soil is determined.

It can be expected that as the leachate invades the soil, none of the waste chemical will appear in the effluent at first. Then at some point, the invading leachate will make its way downstream through the soil column, and come out in more or less full strength. An instantaneous breakthrough of the waste liquid never occurs. The breakthrough is always gradual because the invading leachate mixes with the remnant soil water through a process called mechanical dispersion.

Many of the waste constituents in the leachate are attenuated or retarded by the soil. For example, with no retardation or attenuation, breakthroughs would occur at $\mathrm{C} / \mathrm{C}_{\mathrm{o}}$ of 0.5 at 1 pore volume of flow and below. Accordingly, if $\mathrm{C} / \mathrm{C}_{0}$ of 0.5 occurs at 1 pore volume of flow then the effective and total porosity would be equal (i.e., $n=n_{e}$ ). However, if $\mathrm{C} / \mathrm{C}_{\mathrm{o}}$ of 0.5 occurs at less than 1-pore volume of flow then the effective porosity would be reduced by the same percentage of total porosity (Daniel, 1993).

\subsection{Analytical solution to one dimensional contaminant transport equations}

Analytical methods are widely used for calculating the contaminant migration. The best known analytical solution for concentration $\mathrm{C}$ at time $\mathrm{t}$ and depth $\mathrm{z}$ beneath the surface of a barrier, which is assumed to be infinitely deep and subject to a constant surface concentration $\mathrm{C}_{\mathrm{o}}$ (Ogata and Banks, 1961).

The one dimensional approximate Ogata-Banks equation can be rearranged as:

$$
\frac{C}{C}-\frac{1}{2}\left[\operatorname{erfec}\left(\frac{1-D}{2 \sqrt{U D . / F L}}\right)\right]
$$

where, erfc $=1-\operatorname{erf}(\mathrm{x})$; erfc is the complimentary error function and $\operatorname{erf}(\mathrm{x})$ is the error function of the argument $x$ (Freeze and Cherry, 1979).

$\mathrm{v}=$ Darcy velocity in $\mathrm{cm} / \mathrm{sec}$

$\mathrm{L}=$ Length as in Equation 3

$\mathrm{C}=$ Effluent concentration in $\mathrm{mg} / \mathrm{l}$ 
$\mathrm{C}_{\mathrm{o}}=$ Influent concentration in $\mathrm{mg} / \mathrm{l}$

$\mathrm{x}=$ depth

$\mathrm{R}_{\mathrm{f}}=$ Retardation factor, where $\mathrm{R}$ is given by equation $\mathrm{R}_{\mathrm{f}}=\mathrm{v}_{\mathrm{gw}} / \mathrm{v}_{\mathrm{sp}} ; \mathrm{v}_{\mathrm{gw}}$ is velocity of ground water and; $\mathrm{v}_{\mathrm{sp}}$ is velocity of reactive species of concern.

However, for predicting the effective diffusion coefficient of ionic species of interest using column experiments, a modified form of the above equation is used. The column experiment results are commonly reported in terms of number of pore volume that have passed through packed soil column wherein one pore volume, is the cross sectional area of the column (A) times its length (L) times the porosity (n) i.e., ALn (Equation 3).

Total number of pore volume $\mathrm{U}$ is total discharge divided by value of one pore volume:

$$
\begin{aligned}
& \mathrm{U}=\mathrm{vnAt} / \mathrm{ALn}=\mathrm{vt} / \mathrm{L} \\
& \mathrm{J}_{0.84}=\left[(\mathrm{U}-1) / \mathrm{U}^{1 / 2}\right] \text { when } \mathrm{C} / \mathrm{C}_{\mathrm{o}}=0.84 \\
& \mathrm{~J}_{0.16}=\left[(\mathrm{U}-1) / \mathrm{U}^{1 / 2}\right] \text { when } \mathrm{C} / \mathrm{C}_{\mathrm{o}}=0.16
\end{aligned}
$$

where $\mathrm{J}_{0.84}, \mathrm{~J}_{0.16}$ are factors for simplification at 0.84 and 0.16 break through and Equation 2 is simplified and used as shown in Equation 6.

from which,

$$
\begin{gathered}
\mathrm{D}_{\mathrm{e}}=\mathrm{vL} / 8\left[\mathrm{~J}_{0.84}-\mathrm{J}_{0.16}\right]^{2} \\
\mathrm{D}_{\mathrm{e}}=\text { Effective diffusion co-efficient (units } \mathrm{cm}^{2} / \mathrm{sec} \text { ) }
\end{gathered}
$$

In addition to the above modified Ogata \& Bank's equation another expression for calculating the effective diffusion coefficient of ionic species of interest are given by Fried and Combarnous (1971) as follows:

$$
D_{e}=\frac{1}{8}\left[\frac{x-v t_{0.16}}{\sqrt{t_{0.16}}}-\frac{x-v t_{0.84}}{\sqrt{t_{0.84}}}\right]^{2}
$$

where $\mathrm{t}_{0.16}=$ time at $\mathrm{C} / \mathrm{C}_{\mathrm{o}}=0.16$ and $\mathrm{t}_{0.84}=$ time at $\mathrm{C} / \mathrm{C}_{\mathrm{o}}=0.84$.

The main objective of this work is to predict the vulnerability of the dumpsite using DRASTIC Model and with the available experimental data theoretical models are used to evaluate the behavior of some pollutants to similar soils.

\section{MATERIAL AND METHODS}

Bangalore district is situated in the heart of South Deccan of peninsular India, it is on a ridge top running through the middle of the Mysore plateau from west to east at an average elevation of 900 meters above sea level. Soil Samples were collected from the dumpsite located at Bommasandra industrial area on Hosur Road, Bangalore. Four soil samples were collected from four different stations. The soil samples were collected by open excavation from a depth of one meter from the natural ground. The area has a distinct red soil and the underlying geology is mostly granite and gneiss. The soil was dried and passed through the IS sieve size of 425 microns. The cation exchange capacity of the soil ranges from 18.5 meq/100g to $19.06 \mathrm{meq} / 100$ by Ammonium Acetate extraction method. Specific gravity test 
was conducted using a specific gravity bottle as per IS 2720 (Part III sec I) (Indian..., 1980). The liquid limit test of soil was determined by cone penetrometer method as per IS 2720 (Part V) (Indian... 1985a). Liquid limit of a soil is taken as the water content corresponding to 20 $\mathrm{mm}$ penetration, from a line drawn with respect to water content and penetration. The plastic limits of the soils were obtained as per standard method IS 2720 (Part V) (Indian... 1985a). Shrinkage limit test is conducted as per IS 2720-1972 (Part VI) (Indian... 1972). Grain-size distribution: The percentage of various sizes of particles in a given dry soil sample is found by a particle size analysis or mechanical analysis. The mechanical analysis is performed in two stages: sieve analysis and sedimentation analysis (Bureau of Indian Standards (BIS) which is a regulatory body established by the Government of India to standardize all testing methods and standard practices in the form of design codes. These standards are consistent with ASTM (American standard testing methods) and British standards. It takes into consideration Indian conditions which are unique due to geographical and climatic conditions). Chemical analyses of ground water were done according to standards methods for the examination of water and waste water. DRASTIC Index for the given dumpsite was calculated as enumerated above.

Applied Contaminant Transport Modeling is the first complete resource designed to provide clear coverage of the basic principles of solute transport simulation including the theory behind the most common numerical techniques for solving transport equations, and step-by-step guidance on the development and use of field-scale models. Analysis of contaminant transport has the application in the design of secure waste storage facilities, in the assessment of the effects of a wide range of industrial and mining activities on the groundwater system and evaluation of remedial works carried out to rectify ground water contamination.

To get an overview of the behavior of contaminants at the dumpsite for similar soil, disturbed samples have been used for column study (Maya , 2003). Column experiments were carried out in the Department of Civil Engineering of the Indian Institute of Science for various soils and for different chemical species. The diffusion coefficients used are literature diffusion coefficients given by Freeze and Cherry (1979) and experimental diffusion coefficients obtained from earlier work of these authors.

The column assembly consists of plexiglass of $32 \mathrm{~cm}$ length, $9.2 \mathrm{~cm}$ inner diameter, and $0.5 \mathrm{~cm}$ thick. The plexiglass is attached to the base plate which houses a filter paper and a porous stone. The soil specimen is pressed into plexiglass cylinder using a screw jack to ensure uniform compaction for the entire specimen. Once the soil sample was in place one or more set of porous stone and filter paper are placed at the top and capped with top plate. The influent line is connected at the bottom of the column assembly and effluent line at the top to collect the effluent. Contaminants of known concentration were passed through the column assembly and the effluent was collected and analyzed for their concentration, this was continued till breakthrough occurred.

The diffusion coefficients presented are expected to take into consideration not only tortuosity of soils but also various attenuation processes that occur while the ions migrate through soil. To verify the extent to which they represent various processes that occur through the soil, it is proposed to predict the breakthrough curves using these diffusion coefficients and soil properties and compare with actual breakthrough curves obtained experimentally. Literature and experimental curves are obtained considering both advection and diffusion as main processes for contaminant migration Freeze and Cherry (1979).

In the present study diffusion coefficient obtained by Ogata \& Bank's method is adopted and the contaminant transport behavior is studied by developing a computer program using MATLAB-7. 


\section{RESULTS AND DISCUSSION}

In the present study, an attempt is made to carry out characterization of contaminated dump site in Bommasandra industrial area, Bangalore. Analysis of both water and soil samples shows that the concentration of Sodium, Sulphate, Calcium and Chloride ions are found abundantly. Water samples collected from the nearby bore wells were analyzed for various water quality parameters. Results of the analysis show that many of the water quality parameters such as total hardness, chloride content, fluoride content, alkalinity, BOD, COD, $\mathrm{pH}$ are beyond the permissible limit. In almost all the water samples hardness is found to be in the range of 160 to $354 \mathrm{mg} / \mathrm{l}$ and this is attributed to presence of dissolved minerals such as Carbonates and bicarbonates of calcium, magnesium and also chloride, sulphate of calcium and sodium. The iron content is in the range of 0.78 to $0.90 \mathrm{mg} / 1$ which is higher than the prescribed limit; see details in Table 2, Table 3 and Table 4.

The DRASTIC Index of selected dumpsite is 146. The higher the DRASTIC index means the greater the groundwater pollution potential. The index number is a relative numerical value and is of value only with respect to other numbers generated by the same DRASTIC Index. Thus from the Drastic index number shown in Table 1 and calculated shown in Table 5 it can conclude that the selected dump site is moderately vulnerable to pollutants.

To model the transport of contaminants, mathematical models are available and can be used. In the present study an attempt was made to predict the migrating behavior of selected chemical species, which are abundantly available in both soil and water.

For design of soil liners compacted soil liners are always preferred. The permeability shall be less than $1.0 \mathrm{e}-7 \mathrm{~cm} / \mathrm{s}$. Hence based on extensive literature references, values of velocity are selected in the given range. For plotting the variation of relative concentration $(\mathrm{C} / \mathrm{C} 0)$ with time, experimental and literature values of diffusion coefficients, velocity $(\mathrm{v})$ are substituted for the ions considering thickness of the soil column and a computer program developed using MATLAB-7. From this program the variation of $\mathrm{C} / \mathrm{C} 0$ with time and the depth of migration with time are plotted using literature and experimental data for different chemical species. Also the comparison graphs are plotted between literature and experimental values as shown in Figure 1, Figure 2, and Figure 3. The migrating behavior of selected chemical species namely sodium, sulphate, calcium and chloride shows that sodium ions are retarded better when compared to other anions such as chloride and sulphate. This might be due to retention of sodium in place of exchangeable calcium present in the soil. Normally, sodium cannot be replaced by calcium. But in the presence of sulphate ion, calcium can form insoluble salt and is removed from ion complex of the clay. Then the sodium occupies the exchangeable position and hence it is retained.

The breakthrough curves, obtained by modeling, clearly show that the time required for sodium to reach relative concentration $(\mathrm{C} / \mathrm{C} 0=0.5)$ of 0.5 is 40 years without retardation and 48 years with retardation. For chloride it is observed that the breakthrough curve with retardation factor takes 44 years as compared to 38 years without retardation. Similarly for sulphate the curve with retardation factor takes more time to reach the breakthrough time of 48 years as compared to 37 years without retardation for sulphate. Hence, the effect of retardation factor and diffusion coefficient plays a vital role in the contaminant transport processes. 
Table 2. Results of grain size analysis.

\begin{tabular}{ccccc}
\hline $\begin{array}{c}\text { Station } \\
\mathbf{n}^{\mathbf{0}}\end{array}$ & $\begin{array}{c}\text { Clay } \\
\mathbf{( \% )}\end{array}$ & $\begin{array}{c}\text { Silt } \\
\mathbf{( \% )}\end{array}$ & $\begin{array}{c}\text { Sand } \\
\mathbf{( \% )}\end{array}$ & $\begin{array}{c}\text { Gravel } \\
\mathbf{( \% )}\end{array}$ \\
\hline 1 & 16 & 48 & 32 & 4 \\
2 & 18 & 55 & 26 & 1 \\
3 & 18 & 57 & 24 & 1 \\
4 & 18 & 52 & 29 & 1 \\
\hline
\end{tabular}

Table 3. The Physico-chemical properties of the soils used in the study.

\begin{tabular}{lrrrr}
\hline \multicolumn{1}{c}{ Property } & Station $\mathbf{1}$ & Station $\mathbf{2}$ & Station $\mathbf{3}$ & Station $\mathbf{4}$ \\
\hline Specific gravity (no units) & 2.51 & 2.53 & 2.51 & 2.54 \\
Liquid Limit (\%) & 35.75 & 35.88 & 35.30 & 35.70 \\
Plastic Limit (\%) & 22.01 & 20.23 & 21.0 & 21.65 \\
Shrinkage Limit (\%) & 15.49 & 15.19 & 16.69 & 16.55 \\
Max dry density $\left(\mathrm{g} / \mathrm{cm}^{3}\right)$ & 1.74 & 1.74 & 1.72 & 1.70 \\
Optimum moisture content (\%) & 27.1 & 27.6 & 28.1 & 27.3 \\
Cation exchange capacity (meq/100g) & 19.06 & 18.8 & 18.5 & 18.5 \\
Specific surface area $\left(\mathrm{m}^{2} / \mathrm{g}\right)$ & 48 & 50 & 44 & 44 \\
$\mathrm{pH}(\mathrm{no}$ units) & 5.64 & 5.16 & 5.53 & 5.21 \\
$\mathrm{EC}(\mathrm{dS} / \mathrm{m}) 1: 10$ & 0.083 & 0.094 & 0.092 & 0.089 \\
$\mathrm{OC}(\%)$ & 0.62 & 0.28 & 0.73 & 0.29 \\
$\mathrm{~K} \mathrm{~K}_{2} \mathrm{O}(\mathrm{Kg} / \mathrm{ha})$ & 74.55 & 21.30 & 79.88 & 73.98 \\
$\mathrm{Na}(\mathrm{ppm})$ & 29.0 & 31.0 & 23.0 & 33.0 \\
$\mathrm{~S}(\mathrm{ppm})$ & 06 & 08 & 07 & 05 \\
$\mathrm{Ca}(\mathrm{meq} / 100 \mathrm{~g})$ & 1.15 & 1.09 & 1.26 & 1.05 \\
$\mathrm{Mg}(\mathrm{meq} / 100 \mathrm{~g})$ & 1.02 & 0.97 & 0.98 & 0.86 \\
\hline
\end{tabular}

Table 4. Chemical analysis of ground water.

\begin{tabular}{lrrrrrr}
\hline \multicolumn{1}{c}{ Parameter } & Station 1 & Station 2 & Station 3 & Station 4 & Station 5 & Station 6 \\
\hline $\mathrm{pH}$ & 8.4 & 8.2 & 7.6 & 8.8 & 8.5 & 8.1 \\
Total Hardness (mg/l) & 160.0 & 314.0 & 248.0 & 268.0 & 173.0 & 354.0 \\
Calcium (mg/l) & 98.0 & 182.0 & 182.0 & 196.0 & 87.0 & 182.0 \\
Magnesium (mg/l) & 62.0 & 132.0 & 66.0 & 72.0 & 86.0 & 172.0 \\
Total Alkalinity (mg/l) & 184.0 & 140.0 & 139.0 & 159.0 & 167.0 & 134.0 \\
Chloride (mg/l) & 747.5 & 184.0 & 390.0 & 349.9 & 752.3 & 184.0 \\
Dissolved Oxygen & 9.9 & 7.6 & 7.7 & 8.3 & 9.7 & 7.5 \\
(mg/l) & & & & & & \\
Nitrate (mg/l) & 15.0 & 25.0 & 23.5 & 27.0 & 19.0 & 25.0 \\
Sodium (mg/l) & 53.0 & 65.0 & 68.0 & 74.0 & 58.0 & 69.0 \\
Potassium (mg/l) & 3.0 & 2.0 & 10.0 & 8.0 & 5.0 & 2.0 \\
Iron (mg/l) & 0.8 & 0.8 & 0.8 & 0.8 & 0.9 & 0.9 \\
Flouride (mg/l) & 0.7 & 0.7 & 0.6 & 0.8 & 0.8 & 0.6 \\
DO (mg/l) & 7.4 & 7.8 & 7.5 & 7.4 & 7.7 & 7.6 \\
BOD (mg/l) & 176.0 & 80.0 & 48.0 & 56.0 & 178.0 & 90.0 \\
COD $(\mathrm{mg} / \mathrm{l})$ & 367.2 & 412.4 & 357.9 & 447.8 & 381.3 & 422.6 \\
EC $(\mathrm{mS} / \mathrm{cm})$ & 1.80 & 2.09 & 2.17 & 2.12 & 1.85 & 2.02 \\
\hline
\end{tabular}


MOHAMMED, S. A. S.; NAIK, M.; SANAUlLA, P. F.; ZULFIQAR, A. M. N. Studies on contaminant transport, at an industrial waste dumpsite of Bangalore, India. Ambi-Agua, Taubaté, v. 3, n. 3, p. 55-66, 2008. (doi:10.4136/ambi-agua.61)

Table 5. DRASTIC Index number calculations.

\begin{tabular}{lcccc}
\hline Parameter & Range & Rating & Weight & Score \\
\hline Depth to water & $16-20 \mathrm{~m}$ & 3 & 5 & 15 \\
net Recharge & $41-60 \mathrm{~mm}$ & 6 & 4 & 24 \\
Aquifer media & Sand \& gravel & 8 & 3 & 24 \\
Soil media & Loam & 5 & 5 & 25 \\
Topography & $1 \%$ & 10 & 3 & 30 \\
Impact of Vadose zone & Silt and clay & 3 & 4 & 12 \\
Conductivity & $10-25 \mathrm{~m} /$ day & 8 & 2 & 16 \\
\hline Total & & & & 146
\end{tabular}

Table 6. Diffusion coefficients and retardation factors for different ions.

\begin{tabular}{lccc}
\hline Ions & $\begin{array}{c}\text { Diffusioncoefficients } \\
\text { (literature) in } \mathbf{c m}^{2} \text { / sec }\end{array}$ & $\begin{array}{c}\text { Diffusion coefficients } \\
\text { (experimental)in } \\
\mathbf{c m}^{2} / \mathbf{s e c}\end{array}$ & $\begin{array}{c}\text { Retardation } \\
\text { factors, no units } \\
\text { (experimental) }\end{array}$ \\
\hline Sodium & $4.6 \mathrm{e}-6$ & $7.995 \mathrm{e}-6$ & 1.3 \\
Sulphate & $2.0 \mathrm{e}-6$ & $4.136 \mathrm{e}-6$ & 0.5 \\
Sodium & $4.6 \mathrm{e}-6$ & $5.47 \mathrm{e}-5$ & 1.35 \\
Chloride & $5.9 \mathrm{e}-6$ & $4.872 \mathrm{e}-5$ & 1.4 \\
\hline
\end{tabular}

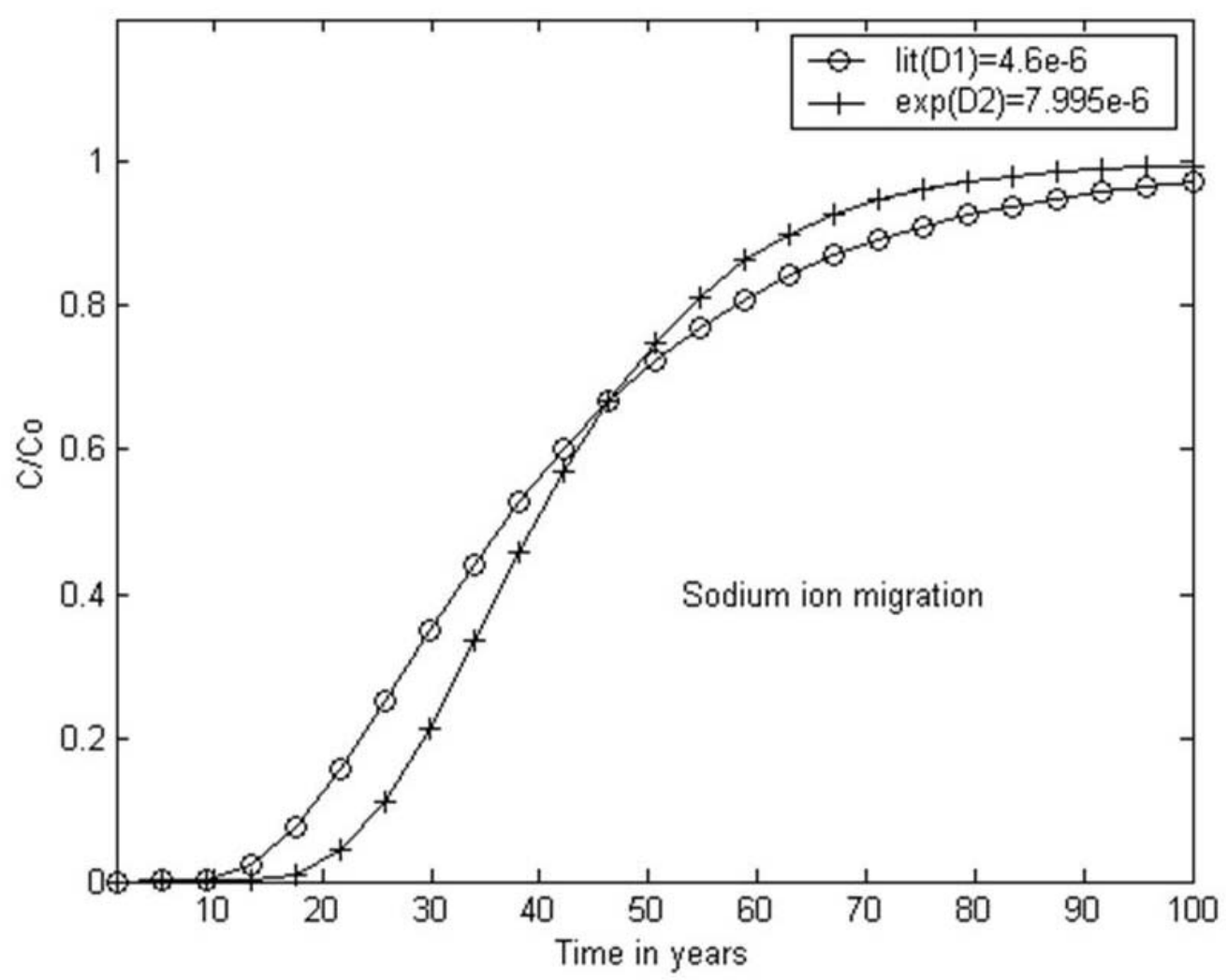

Figure 1. Variation of relative concentration of sodium ion with time for literature and experimental data. 
MOHAMMED, S. A. S.; NAIK, M.; SANAUlLA, P. F.; ZULFIQAR, A. M. N. Studies on contaminant transport, at an industrial waste dumpsite of Bangalore, India. Ambi-Agua, Taubaté, v. 3, n. 3, p. 55-66, 2008. (doi:10.4136/ambi-agua.61)

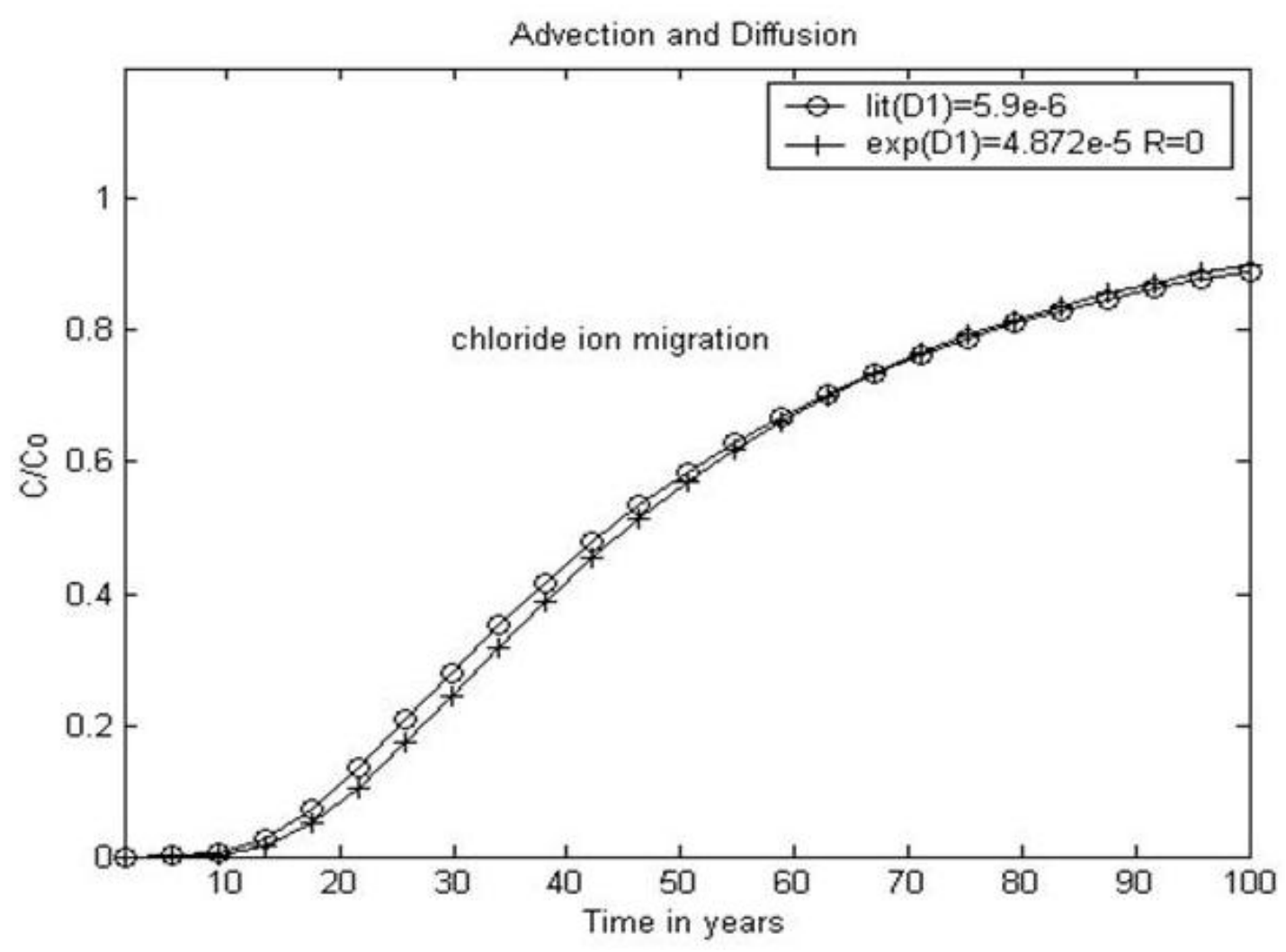

Figure 2. Variation of relative concentration of chloride with time for literature and experimental data.

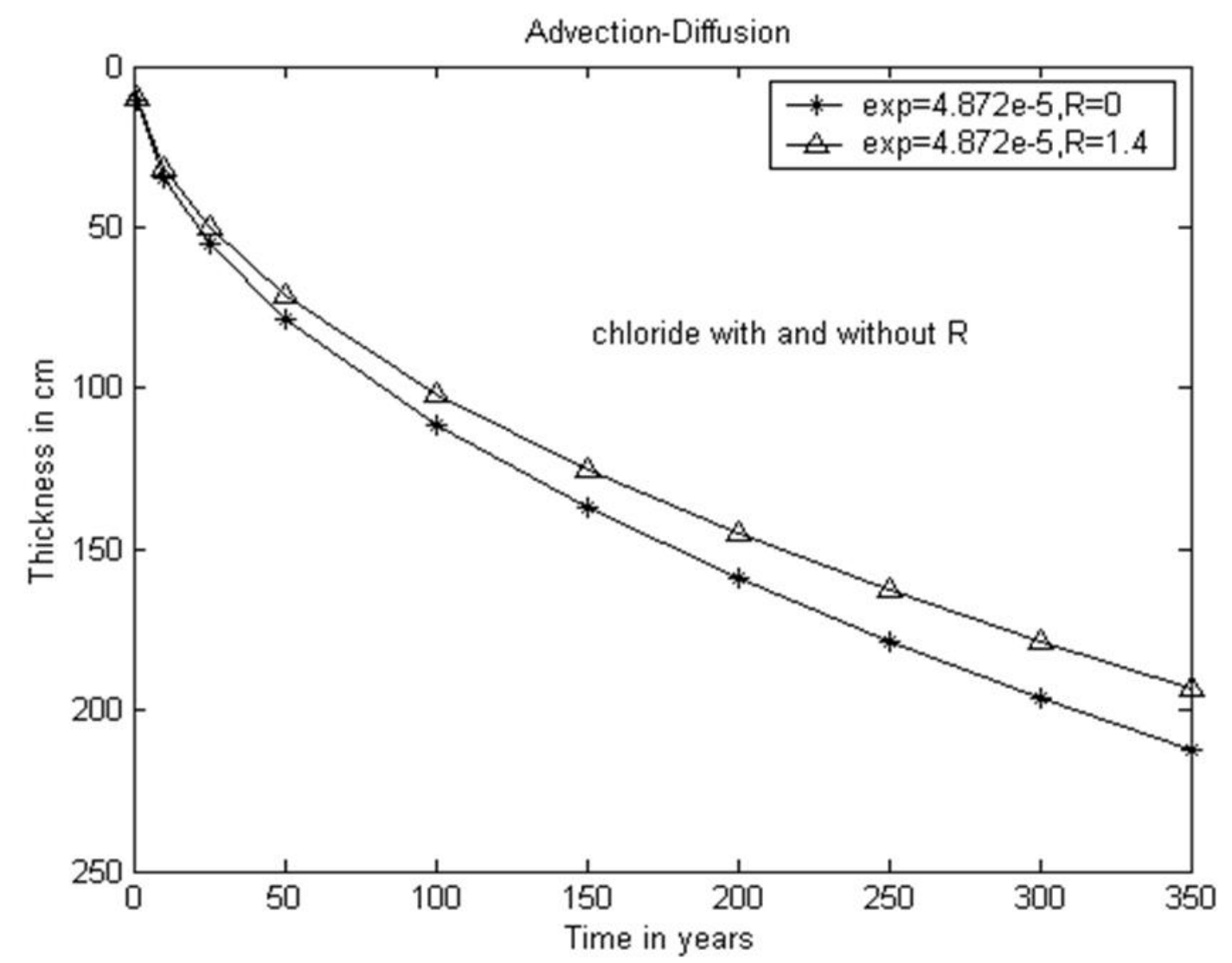

Figure 3. Depth of migration of chloride ion with time using experimental data with $\left(^{*}\right)$ and without retardation $(\Delta)$. 


\section{CONCLUSIONS}

In the present study, characterization of Bommasandra industrial area dumpsite has been carried out. The soil samples were collected from the contaminated site and analyzed for various parameters, the contaminant transport behavior was studied by developing a computer program using MATLAB-7. Based on the work carried out, and the following major conclusions are drawn:

A physico-chemical property of soil clearly shows that the major cations and anions present are sodium, calcium, chloride and sulphate ions, respectively. The concentrations of the above ions are found to be above the permissible limit.

The DRASTIC Index of selected dumpsite was 146, therefore, it can be concluded that the selected dump site is moderately vulnerable to pollutants.

The breakthrough curves obtained by modeling clearly show that the time required for sodium to reach relative concentration $(\mathrm{C} / \mathrm{C} 0=0.5)$ of 0.5 is 40 years without retardation and 48 years with retardation. For chloride it is observed that the breakthrough curve with retardation factor takes 44 years as compared to 38 years without retardation. Similarly for sulphate the curve with retardation factor takes more time to reach the breakthrough time of 48 years as compared to 37 years without retardation for sulphate. Hence, the effect of retardation factor and diffusion coefficient plays a vital role in the contaminant transport processes.

It has been found that the given dumpsite is moderately vulnerable to pollution presently, also by observing the theoretical model with the present state it can fairly predictable the fate of these contaminants in the future. The DRASTIC Index quantifies the present state of dumpsite and the model gives a picture of future to decision makers.

\subsection{Further scope of the study}

Since the site comes under moderately vulnerable to pollution potential, there is a possibility that pollutants are likely to be released from dumpsite and these migrate downwards through unsaturated zone to the water table and then laterally in the direction of the hydraulic gradient in the saturated zone. During the course of migration of pollutants the transport process is controlled by the variety of physical, chemical and biological processes. The contaminant transport process can be studied by conducting pilot plant studies at the contaminated site. A detailed study on characterization of contaminated dumpsite is a must because the nature of contaminants and nature of soil changes periodically. Hence there is a need for continuous monitoring of the quality of water from existent wells.

\section{ACKNOWLEDGEMENTS}

We would like to thank Prof. P.V. Sivapullaiah, Professor of Civil Engineering, Indian Institute of Science (IISc), Bangalore, Mr. B.T .Shivendra and Mrs. Indira R. for their help rendered in carrying out this work. We are highly indebted to the encouragement offered by our Honorable Administrator, Mr. Abdul Hameed S. A., and Principal, Dr. Chaitanya Kumar M.V. of HKBK College of Engineering. 


\section{REFERENCES}

DANIEL D. E. Geotechnical practices for waste disposal. London: Chapman and Hall, 1993.

FREEZE, R. A.; CHERRY, J. A. Groundwater. Englewood Cliffs: Prentice Hall, 1979. 604 p.

FRIED, J. J.; COMBARNOUS, M. A. Dispersion in porous media. Advances Hydroscience, v. 7, p. 169-282, 1971.

GAJENDRAGAD, M. R.; CHANDRAKANTA, R.; NYAMATHI, S. J. Assessment of ground water pollution susceptibility through drastic factor principle- a case study in west coast of India. International Conference on Calibration and Reliability in Groundwater Modelling, The Hague, P 220 -225, September 1990.

INDIAN STANDARDS INSTITUTION. Indian Standard Methods for Testing of Soils IS 2720: part 6, determination of shrinkage factors. New Delhi: Indian Standards Institution, 1972. p. $118-122$.

INDIAN STANDARDS INSTITUTION. Indian Standard Methods for Testing of Soils IS 2720: part 3, determination of specific gravity, section 1, fine grained soils. New Delhi: Indian Standards Institution, 1980. p. $65-69$.

INDIAN STANDARDS INSTITUTION. Indian Standard Methods for Testing of Soils IS 2720: part 5, determination of liquid limit and plastic limit. New Delhi: Indian Standards Institution, 1985a. p. $109-144$.

INDIAN STANDARDS INSTITUTION. Indian Standard Methods for Testing of Soils IS 2720: part 4, grain size analysis. New Delhi: Indian Standards Institution, 1985b. p. $73-91$.

JACKSON, M. L. Soil chemical analysis. New Delhi: Prentice Hall, 1967.

MAYA, N. Influence of diffusion coefficient and retardation factor in contaminant transport through soil liners. 2003. Thesis (Doctoral Degree in Civil Engineering) Indian Institute of Science, Bangalore, 2003.

OGATA, A.; BANKS, A. Solution of the differential equation of longitudinal dispersion in porous media. Fort Collins: US Geological Survey Professions, 1961. Paper 411 -A.

SHAKELFORD, C. D.; DANIEL, D. E. Diffusion in saturated soil: 1 Background, ASCE. Journal of Geotechnical Engineering, v. 177, n. 3, p. 467 - 484, 1991.

WENTZ, C. A. Hazardous waste management. New York: McGraw Hill, 1995. 